\title{
Economic Analysis of Yield Gap and its Implication on Profitability of Finger Millet (Eleusine coracana L.) Production in Karnataka
}

\author{
S. C. Ravi ${ }^{*}$, K. B. Umesh, and Veerabhadrappa Bellundagi
}

Dept. of Agricultural Economics, College of Agriculture, UAS, GKVK, Bengaluru (560 065), India

\section{Article History}

Manuscript No. AR1561

Received in $15^{\text {th }}$ March, 2016

Received in revised form $30^{\text {th }}$ March, 2016

Accepted in final form $2^{\text {nd }}$ April, 2016

\section{Correspondence to}

E-mail: ravisc3@gmail.com

\section{Keywords}

Finger millet, yield gap, profitability, distress, synergistic relationship

\begin{abstract}
The present study was carried out in Bengaluru rural and Ramanagara districts of Karnataka to determine the extent of Yield gap in rainfed and irrigated situation and its implication on profitability of finger millet production. Primary data was collected from 30 rainfed and 30 irrigated farmers in each districts. Secondary data on experimental station yield and front line demonstration yield was obtained from All India Co-ordinated Small Millets Improvement Project, Bengaluru. Results revealed that yield gap was higher in rainfed situation (19.66 $\left.\mathrm{q} \mathrm{ha}^{-1}\right)$ compared to irrigated situation $\left(7.16 \mathrm{q} \mathrm{ha}^{-1}\right)$. Yield gap II (Y $\mathrm{g}$ II) was found to be $6.43 \mathrm{q} \mathrm{ha}^{-1}$ and $4.82 \mathrm{q} \mathrm{ha}^{-1}$ in rainfed and irrigated situations, respectively. The results also implied that, if $\mathrm{Y}_{\mathrm{g}} \mathrm{II}$ is reduced by $50 \%$, then the farmers who are comprehending the negative net returns under rain fed situation can reduce their loss to just ₹ $663 \mathrm{ha}^{-1}$ from ₹ $5912 \mathrm{ha}^{-1}$ and if the $\mathrm{Y}_{\mathrm{g}} \mathrm{II}$ is reduced by $75 \%$ the farmers would realize a profit of ₹ $1,945 \mathrm{ha}^{-1}$. In irrigated situation the farmers can realize a higher profit of ₹ 11,201 and ₹ 13,344 ha $^{-1}$, if $\mathrm{Y}_{\mathrm{g}} \mathrm{II}$ is reduced by $50 \%$ and $75 \%$ respectively. There exists a synergistic relationship between yield gap and profitability. Reducing yield gap is one of the methodologies other than Minimum Support Price (MSP) to condense the distress of the farmers. Hence serious attempts are needed to narrow down the yield gap.
\end{abstract}

\section{Introduction}

Finger millet (Eleusine coracana L.) is an important staple food and fodder crop in many parts of Eastern and Southern Africa, as well as in South Asia. It is also used as a major substitute for rice among the diabetic patients and also the diet conscious people. Nutritionally, when finger millet is used as a whole grain, it is rich in protein and minerals in comparison to all other cereals and millets. Of all the cereals and millets, finger millet has the highest amount of calcium and potassium. It has high content of mineral matter and calcium. It is one of the remarkable sources of protein, making it perfect for vegetarian diets. The Nutritional value of finger millet $100 \mathrm{~g}^{-1}$ is as follows, Protein: $7.7 \mathrm{~g}$, Carbohydrate: $72.6 \mathrm{~g}$, Calcium: $370 \mathrm{mg}$, Iron: $3.9 \mathrm{mg}$, Vitamin A: $0.48 \mathrm{mg}$, Thiamine (B1): $0.42 \mathrm{mg}$, Riboflavin (B2): $0.19 \mathrm{mg}$, Niacin (B3): $1.1 \mathrm{mg}$ (Patil and Sawant, 2012). Finger millet is the staple diet in many villages across South Karnataka. Finger millet is majorly consumed as Finger millet ball, roti, dosa and value added products like biscuits, malt and mixture. Besides grain, Finger millet fodder is an important feed in the livestock sector for draught and dairy animals.

In India, Finger millet is mainly grown in Karnataka, Tamil Nadu, Uttarakhand and Maharashtra. More than $80 \%$ of the crop is grown as Kharif crop. In 2011-12 India produced 19.29 lakh $\mathrm{t}$ of Finger millet from an area of 11.75 lakh $\mathrm{h}$ with an average productivity of $1,641 \mathrm{~kg} \mathrm{ha}^{-1}$. Karnataka tops the Indian Finger millet production with a contribution of $67 \%$ (DES, 2011-12). In Karnataka, Finger millet is mainly grown in Bengaluru Urban, Bengaluru Rural, Ramanagara, Kolar, Mysore, Mandya, Hassan, Tumkur and Chikkmagaluru districts. In Karnataka, finger millet is grown in an area of 6.80 lakh ha, with an annual production of 12.72 lakh $\mathrm{t}$ and productivity of 1,955 $\mathrm{kg} \mathrm{ha}^{-1}$ (DES, 2011-12).

The euphoria of "Green Revolution" in India has made a rapid stride in increasing the food production from 51 million tonnes in 1950s to $264 \mathrm{mt}$ in 2014-15. Despite of this great achievement farm sector is not encouraging in the recent period. Farmers' suicides, indebtedness and distress are increasing day by day. This may be because of vagaries of monsoon, less productivity, un-remunerative 
prices and market related issues. Many researchers have opined that increasing the productivity and correcting the market problems can reduce the distress of the farmers. The main thing to be noted in this regard is that the actual yields obtained by the farmers are considerably lower than those obtained in the demonstration plots and research stations/ farms indicating that there exists a considerable untapped yield potential. The concept of yield gaps in crops originated from different constraint studies carried out by International Rice Research Institute (IRRI) during the seventies. The first step towards reducing yield gaps $\left(\mathrm{Y}_{\mathrm{g}}\right)$ is to obtain realistic estimates of their magnitude. Though country has achieved self-sufficiency in cereal production, there is migration of the farmers and agricultural labour to nearby cities. Analysing the pros and cons of yield gap and the factors for yield gap forms a basis for planning further research, policy makers and extension strategies. Thus, addressing the issue of yield gap and identifying the factors responsible for the gap is important both for achieving food security as well as to increase the farmers' income.

Yield gaps in crops are the present challenges and are needed to be addressed for the sustainable crop production and also to increase the profitability. Evidences from the past studies reveal that yield gap exists in all the crops (Saurabh et al., 2015; Surendra et al., 2013; Ramarao, 2012). Keeping this in mind the present study was undertaken with overall objective of estimating the magnitude of yield gaps, factors contributing to yield gap in Finger millet production in Karnataka and analysing impact of yield gap under both rainfed and irrigated situations.

\section{Materials and Methods}

\subsection{Primary and secondary data collection}

The study was carried out in Bengaluru rural and Ramnagara districts of Karnataka during agriculture year 2014-15. Before finding yield gap it is necessary to ensure that the year selected for study must be a normal agriculture year with sufficient rainfall. If the analysis is conducted in the drought year we may not get the true estimate. Hence only one year was selected for the analysis. These two districts were purposefully selected as these districts ranked second and third in productivity (DES, 2011-12) of Finger millet crop respectively. Bengaluru urban district ranked first in productivity but was not taken as study area because of urbanization. Random sampling technique was employed for the selection of sample farmers. 60 sample farmers were selected randomly in each district. 60 sample farmers comprised of 30 rainfed Finger millet growing farmers and 30 irrigated Finger millet growing farmers. Totally primary data was collected from 120 Finger millet growing farmers.
Secondary data on yield of Finger millet crop obtained in experimental station (research station) and front line demonstration (FLD) were collected from All India CoOrdinated Small Millets Improvement Project (AICSMP), University of Agricultural Sciences, G.K.V.K., Bengaluru.

\subsection{Estimation of yield gap}

To estimate the yield gaps, the methodology developed by the International Rice Research Institute (IRRI) was employed. Yield gap is the difference between the potential yield (maximum attainable yield) and the farm level yield. Potential yield $\left(\mathrm{Y}_{\mathrm{p}}\right)$ is the yield obtained at experimental or research station with no physical, biological and economic constraints and with known management practices at a given point of time in a given ecology. Farm level yield $\left(\mathrm{Y}_{\mathrm{a}}\right)$ is the average farmers yield in a given area at the same point of time in the same ecology.

Instead of comparing the actual farm yield directly to the experimental station yield, a yield level intermediate between the two is introduced. That yield level is called the potential farm yield or front line demonstration yield $\left(\mathrm{Y}_{\mathrm{d}}\right)$ and it is the yield obtained in the farmer's field from the improved technology under the close supervision of extension agent. Front line demonstration yield was not available for irrigated situation. Hence the average of farmers' yield whose yield was more than the average yield $\left(30.34 \mathrm{q} \mathrm{ha}^{-1}\right)$ obtained was taken as progressive farmers yield and it was found to be $35.16 \mathrm{q} \mathrm{ha}^{-1}$. The yield gap is thus divided into yield gap I and yield gap II.

Total yield gap $(\mathrm{TYG})=\mathrm{Y}_{\mathrm{p}}-\mathrm{Y}_{\mathrm{a}}$

\subsubsection{Yield Gap-I (YG-I)}

It is the difference between the potential yield and the potential farm yield or the demonstration plot yield.

$\mathrm{YG}-\mathrm{I}=\mathrm{Y}_{\mathrm{p}}-\mathrm{Y}_{\mathrm{d}}$

YG-I \% $=\left[\left(Y_{p}-Y_{d}\right) \div Y_{p}\right]^{*} 100$

\subsubsection{Yield Gap-II (YG-II)}

It is the difference between the potential farm yield and the actual yield.

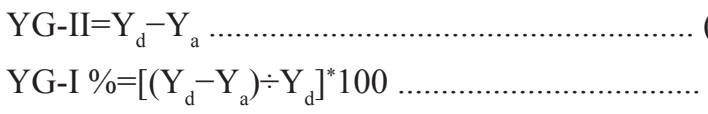

\subsubsection{Index of yield gap (IYG)}

It is the ratio of the difference between the potential yield and the actual yield to the potential yield, expressed in percentage.

$\mathrm{IYG}=\left[\left(\mathrm{Y}_{\mathrm{p}}-\mathrm{Y}_{\mathrm{a}}\right) \div \mathrm{Y}_{\mathrm{p}}\right] \times 100$

\subsubsection{Index of realized potential yield (IRPY)}

It is the ratio of the actual yield to the potential yield obtained in UAS, GKVK, Bengaluru, expressed in percentage. 
IRPY $=\left[\mathrm{Y}_{\mathrm{a}} \div \mathrm{Y}_{\mathrm{p}}\right] \times 100$

\subsubsection{Index of realized potential farm yield (IRPFY)}

It is the ratio of the actual yield to the potential farm yield expressed in percentage

IRPFY $=\left[Y_{\mathrm{a}} \div \mathrm{Y}_{\mathrm{d}}\right] \times 100$

\subsection{Factors responsible for yield gap II}

To analyse the factors responsible for yield gap II in rainfed and irrigated Finger millet production, multiple linear regression analysis was employed, considering yield gap II as dependent variable and years of schooling, age of farmers, human labour productivity, fertilizer productivity and technological guidance as independent variables. Dummy variable 1 was assigned for those who were receiving technological guidance and 0 for others. In the process of analysis, education level in years of schooling was used as proxy for managerial capacity and age of the farmer was taken as proxy for farming experience. The variables are selected such that these do not increase the cost of cultivation. In our further analysis of impact of yield gap on profitability cost is assumed to be constant.

The empirical model specified is as follows:

$\mathrm{Y}=\mathrm{a}+\mathrm{b}_{1} \mathrm{X}_{1}+\mathrm{b}_{2} \mathrm{X}_{2}+\mathrm{b}_{3} \mathrm{X}_{3}+\mathrm{b}_{4} \mathrm{X}_{4}+\mathrm{b}_{5} \mathrm{D}+\mathrm{e}$

Where,

$\mathrm{Y}=\mathrm{Yield}$ gap II $\left(\mathrm{q} \mathrm{ha}^{-1}\right)$

$\mathrm{X}_{1}=$ Education (Years of schooling)

$\mathrm{X}=$ Age $($ Years $)$

$\mathrm{X}_{3}=$ Human labour productivity (quintal per man day)

$\mathrm{X}_{4}=$ fertilizer productivity (quintal per rupee of

expenditure on fertilizer)

$\mathrm{D}=$ Technological guidance $(1=$ technology guidance and $0=$ others)

\section{Results and Discussion}

\subsection{Yield gap in rainfed and irrigated finger millet cultivation}

It is evident from the Table 1 that, there exists a sizeable gap in Finger millet productivity between the research station, front line demonstration or progressive farmers and the sample farmers' field level yield both in rainfed and irrigated cultivation. Estimation of yield gap is important as it forms a base to identify the yield realized by farmers and to form policies regarding increasing the productivity at farmers level. gap.

\subsubsection{Rainfed finger millet}

Finger millet yield realised in the research station $\left(37.5 \mathrm{q} \mathrm{ha}^{-1}\right)$ and on demonstration plots $\left(24.27 \mathrm{q} \mathrm{ha}^{-1}\right)$ were substantially higher than on farmers' fields $\left(17.84 \mathrm{q} \mathrm{ha}^{-1}\right)$. The magnitude
Table 1: Finger millet yield levels realised and the estimated yield gaps

\begin{tabular}{|c|c|c|c|c|c|c|}
\hline \multirow{2}{*}{$\begin{array}{l}\text { Part- } \\
\text { iculars }\end{array}$} & \multirow{2}{*}{$\begin{array}{c}\text { Exper- } \\
\text { imental } \\
\text { Station } \\
\text { yield }\end{array}$} & \multirow{2}{*}{$\begin{array}{l}\text { Front } \\
\text { line } \\
\text { demon- } \\
\text { stration } \\
\text { yield }\end{array}$} & \multirow{2}{*}{$\begin{array}{l}\text { Far- } \\
\text { mers } \\
\text { yield }\end{array}$} & \multicolumn{3}{|c|}{$\begin{array}{l}\text { Yield } \\
\text { Gap (q) }\end{array}$} \\
\hline & & & & I & II & $\mathrm{I}+\mathrm{II}$ \\
\hline $\begin{array}{l}\text { Rai-nfed } \\
\text { (q) }\end{array}$ & 37.5 & 24.27 & 17.84 & $\begin{array}{l}13.23 \\
35.28\end{array}$ & $\begin{array}{c}6.43 \\
26.51\end{array}$ & $\begin{array}{l}19.66 \\
52.42\end{array}$ \\
\hline $\begin{array}{l}\text { Irrigated } \\
\text { (q) }\end{array}$ & 37.5 & 35.16 & 30.34 & $\begin{array}{l}2.34 \\
6.24 \\
\end{array}$ & $\begin{array}{c}4.82 \\
13.70\end{array}$ & $\begin{array}{c}7.16 \\
19.09\end{array}$ \\
\hline
\end{tabular}

Note: 1: Yield gap I=Exp. yield-FLD yield; 2: Yield gap II=FLD yield-Farmers yield; 3: Yield gap=Yield gap I+yield gap II; 4: Figures in parentheses indicate percentage of yield gap

of total yield gap was found out to be $19.66 \mathrm{q} \mathrm{ha}^{-1}$. The results are in accordance with the findings of Anon (2010). Yield gap comprised of relatively higher magnitude of yield gap-I (35.28\%) than yield gap-II (26.51\%) (Gaddi et al. 2002; Gaddi et al., 2003). Yield gap I exists due to the fact that experiments are conducted on scientific lines and are equipped with all the requisite resources including the technical input on the research stations, the differences in environmental conditions, management practices, non-transferable component of technology like cultural practices and the conditions in which Finger millet crop is grown (Krishnamurthy et al., 1997; Deokate, 2013). The experiment will be mainly conducted in a smaller area with intensive care but the same situation cannot be seen in farmers case and as well as in the front line demonstration plots which is the main reason for the existence of huge yield gap (61.79\%).

\subsubsection{Irrigated finger millet}

Yield obtained in the experimental station was $37.5 \mathrm{q} \mathrm{ha}^{-1}$. Since front line demonstration yield was not available for irrigated situation, the average of farmers' yield whose yield was more than the average yield (30.34 $\left.\mathrm{q} \mathrm{ha}^{-1}\right)$ obtained was taken as progressive farmers yield and it was found to be $35.16 \mathrm{q} \mathrm{ha}^{-1}$. The total yield gap was found to be $7.16 \mathrm{q} \mathrm{ha}^{-1}$. This comprised of relatively higher magnitude of yield gap-II (6.24\%) than yield gap-I (13.70\%) (Surendra et al., 2013). Yield gap II is also called as extension gap, which is mainly because of differences in management practices and operations. Yield gap II is of more importance as this gap can be bridged easily by intensive extension efforts. The demonstration trials were carried out under the supervision of agricultural extension workers in the farmers field itself where technical assistance regarding crop production is given by extension workers, which is not seen in farmers' situation. 


\subsection{Indices of yield gap}

Various indices of yield gaps were worked out and are presented in Table 2. The estimated index of yield gap worked out to be 52.42 and $19.09 \%$ in rainfed and irrigated situation indicating that there, exists a tremendous scope to improve the profitability of Finger millet production in the study area. The farmers realized 73.51 and $86.29 \%$ (Index of realised potential farm yield) of the potential farm yield in rainfed and irrigated situation respectively. Thus, if the farmers adopt the production technology and inputs as used on demonstration plots, the sample farmers would have realized 26 and 14\% of more Finger millet output than the present level in rainfed and irrigated situation respectively.

\subsection{Factors responsible for yield gap II}

The analysis was made by using simple multiple linear regression function and the results are presented in the Table 3. Results indicated that, in rainfed situation as the education of the farmers (years of schooling) increases the yield gap II reduces by $0.02 \mathrm{q} \mathrm{ha}^{-1}$. Similarly increase in fertilizer productivity reduces yield gap by $0.28 \mathrm{q} \mathrm{ha}^{-1}$. Shift in the intercept because of technological guidance is $0.42 \mathrm{q} \mathrm{h}^{-1}$. Whereas, in case of irrigated situation, yield gap II reduces with the increase in age of the farmers, fertilizer productivity 0.009 and $0.03 \mathrm{q} \mathrm{ha}^{-1}$, respectively. Shift in the intercept because of technological guidance is $1.39 \mathrm{q} \mathrm{ha}^{-1}$. It can be noticed that, in both the cases technological guidance and fertilizer productivity had a great potential to decrease extension gap (yield gap II) through increased extension efforts, reflecting the need of extension services in educating farmers regarding the improved technology (Krishnamurthy et al., 1997; Saurabh et al., 2015).

\subsection{Impact of yield gap on profitability}

Yield gap has lot of implications on the profitability. Reduction in yield gap helps in increasing the profitability. Since, it is not possible to achieve $100 \%$ reduction in yield gap II. Hence an attempt was made to analyse the impact of reduction in yield gap II by $50 \%$ and $75 \%$ on the net returns of farmers in both rainfed and irrigated situation. The reduction

Table 2: Estimated indices of yield gaps in Finger millet production

\begin{tabular}{llcc}
\hline $\begin{array}{l}\text { S1. } \\
\text { no. }\end{array}$ & \multicolumn{1}{c}{ Particulars } & $\begin{array}{c}\text { Rainfed } \\
\text { situation }\end{array}$ & $\begin{array}{c}\text { Irrigated } \\
\text { situation }\end{array}$ \\
\hline 1. & Index of yield gap (IYG) & 52.43 & 19.09 \\
2. & $\begin{array}{l}\text { Index of realised potential } \\
\text { yield (IRPY) }\end{array}$ & 47.57 & 80.91 \\
& $\begin{array}{l}\text { Index of realised potential } \\
\text { farm yield (IRPFY) }\end{array}$ & 73.51 & 86.29 \\
\hline
\end{tabular}

Table 3: Factors affecting the yield gap II

\begin{tabular}{|c|c|c|c|c|}
\hline $\begin{array}{l}\text { S1. } \\
\text { no. }\end{array}$ & Variables & Parameters & Rainfed & Irrigated \\
\hline 1. & Intercept & A & $\begin{array}{l}3.70^{* *} \\
(4.95)\end{array}$ & $\begin{array}{c}2.74 \\
(0.62)\end{array}$ \\
\hline 2. & $\begin{array}{l}\text { Education (years } \\
\text { of schooling) } X_{1}\end{array}$ & $\mathrm{~b}_{1}$ & $\begin{array}{l}-0.02^{*} \\
(-2.38)\end{array}$ & $\begin{array}{l}0.003 \\
(0.02)\end{array}$ \\
\hline 3. & $\begin{array}{l}\text { Age of the farmer } \\
\text { (year) } \mathrm{X}_{2}\end{array}$ & $b_{2}$ & $\begin{array}{c}0.02 \\
(0.83)\end{array}$ & $\begin{array}{l}-0.009 \\
(-0.16)\end{array}$ \\
\hline 4. & $\begin{array}{l}\text { Labour produc- } \\
\text { tivity (q man } \\
\left.\text { day }^{-1}\right) X_{3}\end{array}$ & $b_{3}$ & $\begin{array}{c}2.91 \\
(0.78)\end{array}$ & $\begin{array}{c}2.09 \\
(0.23)\end{array}$ \\
\hline 5. & $\begin{array}{l}\text { Fertilizer produc- } \\
\text { tivity ( } \mathrm{q}^{\mathrm{F}^{-1}} \text { of } \\
\text { expenditure) } \mathrm{X}_{4}\end{array}$ & $\mathrm{~b}_{4}$ & $\begin{array}{l}-0.28^{* *} \\
(-2.97)\end{array}$ & $\begin{array}{l}-0.03^{*} \\
(-2.13)\end{array}$ \\
\hline 6. & $\begin{array}{l}\text { Technological } \\
\text { guidance D }\end{array}$ & $\mathrm{b}_{5}$ & $\begin{array}{l}-0.42^{* *} \\
(-2.76)\end{array}$ & $\begin{array}{l}-1.39^{*} \\
(2.13)\end{array}$ \\
\hline 7. & $\begin{array}{l}\text { Co-efficient of } \\
\text { multiple determi- } \\
\text { nation }\end{array}$ & $\mathrm{R}_{2}$ & 0.47 & 0.45 \\
\hline
\end{tabular}

in yield gap II can be achieved by using the inputs at optimum level and by improving the management practices, for this purpose three different scenarios were considered. The first scenario presents the existing situation, second scenario depicts $50 \%$ reduction in yield gap II and the third scenario represents $75 \%$ reduction in yield gap II. The analysis of the same is presented in the Table 4. As per scenario I, rainfed farmers realized negative returns ( $₹-5,912 \mathrm{ha}^{-1}$ ) whereas, irrigated farmers realized a net return of ₹ $6,933 \mathrm{ha}^{-1}$. With

Table 4: Impact of reduction in yield gap II on the profitability of Finger millet

\begin{tabular}{|c|c|c|c|c|}
\hline Par & $n$ & $\begin{array}{c}\text { I } \\
\text { (Actual } \\
\text { situation) }\end{array}$ & $\begin{array}{c}\text { II } \\
(50 \% \\
\text { reduction } \\
\left.\text { in } \mathrm{Y}_{\mathrm{g}} \mathrm{II}\right) \\
\end{array}$ & $\begin{array}{c}\text { III } \\
(75 \% \\
\text { reduction } \\
\left.\text { in } \mathrm{Y}_{\mathrm{g}} \mathrm{II}\right)\end{array}$ \\
\hline \multirow{2}{*}{$\begin{array}{l}\text { Yield } \\
\left(\mathrm{q} \mathrm{ha} \mathrm{h}^{-1}\right)\end{array}$} & Rainfed & 17.84 & 21.06 & 22.66 \\
\hline & Irrigated & 30.34 & 32.75 & 33.96 \\
\hline \multirow{2}{*}{$\begin{array}{l}\text { Cost of } \\
\text { cultivation } \\
\left(₹ h^{-1}\right)^{*}\end{array}$} & Rainfed & 43,779 & 43,779 & 43,779 \\
\hline & Irrigated & 59,263 & 59,263 & 59,263 \\
\hline \multirow{2}{*}{$\begin{array}{l}\text { Gross return } \\
\left(₹ \mathrm{ha}^{-1}\right)\end{array}$} & Rainfed & 37,867 & 43,116 & 45,724 \\
\hline & Irrigated & 66,196 & 70,464 & 72,607 \\
\hline \multirow{2}{*}{$\begin{array}{l}\text { Net return } \\
\left(₹ h^{-1}\right)\end{array}$} & Rainfed & $-5,912$ & -663 & 1,945 \\
\hline & Irrigated & 6,933 & 11,201 & 13,344 \\
\hline
\end{tabular}

*It is assumed that cost of cultivation remains constant 
the improved scenario (II) of reducing the $\mathrm{Y}_{\mathrm{g}}$ II by $50 \%$ would enable to reduce their loss to just ₹ $663 \mathrm{ha}^{-1}$ in rainfed situation and increase the net return to ₹ $11,201 \mathrm{ha}^{-1}$ in irrigated situation. Whereas, scenario III still provides a brighter prospects of increasing the net return to ₹ $1,945 \mathrm{ha}^{-1}$ and ₹ $13,344 \mathrm{ha}^{-1}$ in rainfed and irrigated situation, respectively.

\section{Conclusion}

Serious attempts are needed to reduce the yield gap, thereby making finger millet a profitable crop. Yield gap II (extension gap) is exploitable and is more important from the farmers' point of view and thus efforts need to be taken to reduce it in both the situations. Narrowing yield gap helps in increasing the productivity, profit level and reduces the distress of the farmers. Increasing the productivity is not merely essential but creating awareness regarding the nutritional value of the crop among the consumers is of prime importance. So that it curtails the increased production and enhances the market opportunities.

\section{Policy Recommendations}

Yield gap II can be reduced by improving the managerial ability of the farmers, providing information about the package of practices and providing timely information by means of intensive extension activities. Farmers must be motivated through farm visits to progressive farmers' field. The link between farmers and extension agents, extension agents and the researchers should be strengthened. Scientists need to make efforts to reduce the yield gap without increasing the cost.

\section{Future Research}

It is evident from the research that, there exists a huge potential to reduce the yield gap in Finger millet. In this particular study only the socio-economic factors affecting the yield gap has been identified. There is a need to identify the genetic factors which are hindering in achieving the potential yield as obtained in the research or experimental plots. Scientists need to consider these genetic factors along with the socio economic factors to evolve with a new variety in this regard. And the concept of identifying the extent of yield gap and the factors responsible for yield gap must be worked out for all the crops.

\section{References}

Anonymous, 2010. Bridging yield gaps in major agricultural crops-Strategy for Karnataka, Karnataka State Department of Agriculture Report, Bangalore, 25-132.

Deokate Tai Balasaheb, 2013. Quantification of yield gaps in different planting types of sugarcane in Maharashtra, Indira Gandhi Institute of Development Research, Mumbai, 1-86.

Gaddi, G.M., Mundianamani, S.M., Basavaraja, H., 2002. Yield gaps and constraints in the production of rabi sorghum in Karnataka-A path coefficient analysis. Agricultural Economics Research Review 15(1), 13-25.

Gaddi, G.M., Mundinamani, S.M., Naik, S.D., 2003. Path Co-efficient analysis of yield gaps in cotton production in Karnataka. Agricultural Situation in India 60(4), 185-192.

Krishnamurthy, M.K., Krishnappa, M.R., Narayanappa, E., Naik, C.M., 1997. An analysis of yield gap in Sugarcane. Karnataka Journal of Agricultural Sciences 10(3), 831-833.

Patil, Y.R., Sawant, R.S., 2012. A role of starch of Eleusine coracana Gaertn (Finger millet satwa) in management of mal nutrition. International Research Journal of Pharmacy 3(2), 287-290.

Ramarao, I.V.Y., 2012. Efficiency, yield gap and constraints analysis in irrigated vis-a-vis rainfed sugarcane in North Coastal Zone of Andhra Pradesh. Agricultural Economics Research Review 25(1), 167-171.

Saurabh Verma, Verma, D.K., Giri, S.P., Vats, A.S., 2015. Yield gap analysis in mustard cultivation through front line demonstrations in Faizabad district of Uttar Pradesh. Annals of Plant and Soil Research 17(4), 257-260.

Singh, S., Singh, R.K., Singh, R., 2013. Enhancing rice and wheat production by bridging yield gap in western Uttar Pradesh of India. Journal of Wheat Research 5(2), 43-47. 